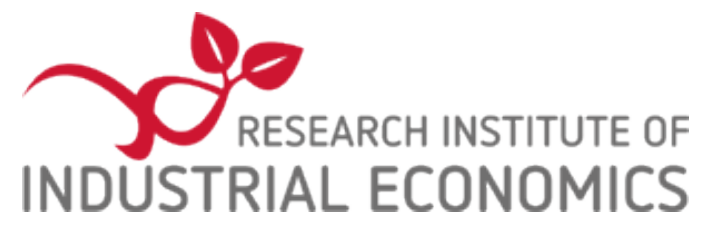

IFN Working Paper No. 1073, 2015

\title{
Swedish Lessons: How Important are ICT and R\&D to Economic Growth?
}

Harald Edquist and Magnus Henrekson 


\title{
Swedish Lessons: How Important are ICT and R\&D to Economic Growth?
}

\author{
By \\ Harald Edquist $^{*}$ and Magnus Henrekson ${ }^{* *}$
}

February 27, 2017

\begin{abstract}
We investigate to what extent ICT and R\&D capital is associated with value added growth in the Swedish business sector. By estimating output elasticities based on data for 47 different industries for the period 1993-2012 we show that ICT and R\&D capital are significantly associated with value added for most specifications. We also divide ICT capital into hardware and software capital. To our knowledge, this distinction has not been made in any previous study at the industry level. In this case only the estimated elasticity of software is significantly different from zero. Finally, we use the growth accounting framework to compare the contribution from ICT and R\&D to value added growth when output elasticities are based on either income shares or weighted least squares (WLS) estimates. The contribution of ICT to value added growth increases from 0.9 to 1.5 percentage points when WLS estimates are used instead of income shares.
\end{abstract}

JEL Codes: O14; O32; O33; O47

Keywords: ICT; R\&D; Software capital; Hardware capital; Industrial change; Panel data.

\footnotetext{
* Corresponding author: Harald Edquist, Associate Professor, Ericsson Research, Färögatan 6, SE-164 80, Stockholm, Sweden. Email: harald.edquist@ericsson.com.

** Magnus Henrekson, Professor, Research Institute of Industrial Economics, (IFN), P.O. Box 55665, SE-102 15, Stockholm, Sweden. Email: magnus.henrekson@ifn.se.
} 


\section{Introduction}

For a long time investment in information and communications technology (ICT) and R\&D has been emphasized as important for technical change and economic growth (e.g., Schumpeter 1942; Nelson 1959; Griliches 1991; Brynjolfsson and McAfee 2014). Since the mid-1990s both value added and productivity have grown rapidly in the Swedish business sector. ${ }^{1}$ The average annual value added growth was 3.4 percent in 1993-2015. This is a strong development compared to many OECD countries (see figure 1).

Evidence from the U.S. economy suggests that the growth rate after 1995 was driven by ICT investments (Oliner and Sichel 2000; Stiroh 2002a; Jorgenson et al. 2008). Together with the U.S. and the UK, Sweden had one of the largest shares of ICT in total investment in the 2000s (OECD 2015b). Research also shows that investment in intangible assets through R\&D is important for growth in value added and productivity (Corrado et al. 2009; Marrano et al. 2009). Sweden's R\&D investment as a share of GDP has also been higher than in most other countries (OECD 2015a).

Given the high rates of aggregate ICT and R\&D investment in Sweden it is of particular interest to explore whether such investments are associated with higher value added. Were this to be the case, it would suggest that ICT and R\&D investments are economically justified, and that countries with a similar industry structure could benefit from investing more in ICT and R\&D. Therefore, we investigate whether ICT and R\&D capital is positively associated with the level of value added across Swedish industries in the period 1993-2012. Moreover, we distinguish between two types of ICT capital - hardware and software - and explore their respective links to the level and growth of value added. Finally, we use the growth accounting framework to investigate the total contribution from ICT and R\&D to economic growth in the Swedish business sector when output elasticities are based on either income shares or weighted least squares (WLS) estimates. More specifically, we investigate the following questions:

\footnotetext{
${ }^{1}$ When the business sector is referred to in this paper it is defined as the non-farm business sector and thus excludes agriculture, forestry and fishing.
} 
- Is there a positive and significant association between high levels of ICT and R\&D capital and value added at the industry level?

- Does the effect of ICT hardware differ from the effect of ICT software?

- Based on the growth accounting framework, what is the contribution from ICT and R\&D when output elasticities are based on income shares or WLS estimates, respectively?

We show that ICT and R\&D capital are significantly associated with value added for most specifications - an increase of ICT capital by 10 percent is associated with an increase in value added by 1.7 percent based on WLS estimates. The corresponding elasticity for R\&D capital is 0.11 , but it is only significant at the 10 percent level. The elasticity is larger and the association stronger when we control for fixed effects.

We also divide ICT capital into hardware and software capital - to our knowledge, this distinction has not been made in any previous study at the industry level, primarily due to data limitations. By making a distinction between software and hardware ICT we can obtain more detailed knowledge on how new technology affects economic development. In this case only the estimated elasticity of software is significantly different from zero. One possible explanation could be that all industries invest in hardware, but only the ones that successfully invest in and implement software enjoy positive effects from ICT.

Finally, we use elasticities based on both WLS estimates or income shares in a growth accounting framework to measure the contribution of ICT and R\&D. We find that the contribution of ICT to value added growth increases from 0.9 to 1.5 percentage points when WLS estimates of elasticities are used instead of income shares. The corresponding figure for $\mathrm{R} \& \mathrm{D}$ is an increased contribution from 0.36 to 0.43 percentage points.

The paper is organized as follows. In Section 2 we summarize findings from earlier research and position our study in the literature. In Section 3 we present the methodological framework and specify our model and in Section 4 we describe our data. Section 5 presents the results, section 6 provides a sensitivity analysis, and Section 7 concludes. 


\section{Related Literature}

OECD (2009a, p. 90) defines ICT as products "intended to fulfil or enable the function of information processing and communications by electronic means, including transmission and display". The economic impact of ICT has been extensively debated since the 1980s when Nobel Laureate Robert Solow famously remarked "You can see the computer age everywhere but in the productivity statistics" (Solow 1987, p. 36). The 1990s productivity boom in the U.S. and several other developed countries was linked to investment in ICT (Oliner and Sichel 2000; Van Reenen et al. 2010).

Based on growth accounting Oliner and Sichel (2000) found that ICT accounted for 1.5 percentage points of the 2.6 percent growth rate per annum of labor productivity in the U.S. business sector in 1996-1999. Gordon (2000) was skeptical of these findings. He asserted that the productivity revival in the U.S. was primarily driven by exceptionally rapid productivity growth in the production of computer hardware, peripherals and telecommunications equipment, while productivity growth in the rest of the economy remained sluggish. But as more data became available, it became increasingly evident that the productivity effects of ICT were substantial in most industries (Stiroh 2002a; Jorgenson et al. 2008). Byrne et al. (2013) showed that the relative contribution of ICT to labor productivity growth remained high in 2004-2012, i.e., after the productivity growth slowdown in the U.S.

While the rate of productivity growth increased sharply in the U.S. after 1995, the growth rate remained sluggish in many countries in Western Europe (van Ark et al. 2008). Both ICT capital deepening and total factor productivity (TFP) increased more slowly in Europe compared to the U.S. van Ark et al. (2008) found that the productivity slowdown in Europe was primarily caused by slower TFP growth in services. One exception was Sweden, where the growth rates of value added and productivity were among the highest in Western Europe.

Based on growth accounting studies alone one cannot establish a clear link between ICT investments and labor productivity growth. However, there are also a number of econometric studies that link investment in ICT to growth in value added and productivity. Gust and Marques (2004) found a strong relationship between the GDP share of ICT production and labor productivity growth in 13 OECD countries for the period 1992-1999. Niebel (2014) 
found a positive relationship between ICT capital and GDP growth for 59 countries in 19952010.

Furthermore, a number of studies explore the cross-country link between specific ICT capital and productivity growth. Röller and Waverman (2001) found a significant relationship between telecommunications infrastructure and aggregate output based on 21 OECD countries in 1971-1990. They found that about one third of economic growth could be attributed to telecommunications after controlling for simultaneity and country specific fixed effects. Likewise, Gruber and Koutroumpis (2011), based on data for 192 countries, found that investment in telecommunications infrastructure contributed 0.20 percentage points to economic growth in high income countries in 1990-2007.

As more micro data have become available, the number of studies estimating the impact of ICT at the firm level has increased. According to Van Reenen et al. (2010) most firm-level studies find a positive and significant association between ICT and productivity and value added. Based on firm-level data Brynjolfsson and Hitt (2003) found that ICT investment had a lagged effect on the growth of value added and TFP. They argue that it takes several years before the full growth contribution of ICT materializes as a result of complementary organizational investments that take time to implement.

The association between ICT capital and the levels of productivity and value added has been thoroughly investigated based on industry level data. For the U.S., Stiroh (2002a) found that ICT intensive industries experienced an accelerated productivity growth in 1995-2000 compared to 1987-1995. The growth differential to other industries was approximately 2 percentage points. Moreover, based on industry data for eighteen OECD countries Spiezia (2012) showed that the average contribution of ICT varied between 0.3 and 1.0 percentage points depending on country. ICT investments were divided into three types: computer equipment, communications equipment and software. In all countries except Finland and Japan computer equipment capital accounted for the largest share of the total ICT contribution.

Basu and Fernald (2007) found that with long time lags, ICT capital growth was positively associated with the industry TFP acceleration. Moreover, O’Mahony and Vecchi (2005) used 
industry data to show a positive return of ICT capital on output growth based on a dynamic panel data approach. Dahl et al. (2010) used panel data for seven EU countries and found that European industries that were relatively ICT intensive before 1995, outperformed the other industries post-1995 in terms of both labor productivity and TFP growth.

Stiroh (2002b) used panel data to analyze the direct effect from the change in ICT capital on output in the U.S. He found a negative association between ICT capital deepening and output. One explanation for this unexpected result could be that the analysis was based solely on data for manufacturing for the period 1984-1999. Based on an updated dataset with a more detailed industry breakdown and the addition of service sectors, Stiroh (2005) found positive correlations between ICT and gross output. However, the ICT coefficients were not significant for all specifications. Nonetheless, the conclusion that ICT played a crucial role for the U.S. productivity revival after 1995 is upheld, although some caution is called for regarding exactly how important ICT has been for U.S. economic growth.

A number of studies have also pointed out the complementarity between ICT and intangible capital (Corrado et al. 2014; Chen et al. 2016). O'Mahony and Peng (2011) find significant interaction effects between ICT and workforce training on labor productivity at the industry level in EU-countries. Thus, there is evidence of complementarity between ICT and workforce training.

According to the Frescati Manual (OECD 2002, p. 30), R\&D is defined as "creative work undertaken on a systematic basis in order to increase the stock of knowledge, including knowledge of man, culture and society, and the use of this stock of knowledge to devise new applications". Just as there is substantial evidence that ICT capital has a positive impact on value added and economic growth, the same is true for R\&D. Both studies based on growth accounting and econometric estimations have found that R\&D contributes to value added and productivity (McMorrow and Röger 2009; Hall et al. 2009). Moreover, estimates based on industry data are generally quite consistent with those obtained from firm data (Hall et al. 2009).

Based on growth accounting estimates Griliches (1991) found that more than half of U.S. TFP growth was attributable to R\&D. Moreover, Edquist (2011) estimated that R\&D 
accounted for nearly 13 percent of labor productivity growth in the business sector in Sweden in 1995-2000. In general, the elasticity of R\&D tends to lie between 0.10 and 0.20 based on econometric estimates of cross sectional data (McMorrow and Röger 2009). Thus, on average a 10 percent increase in $R \& D$ capital services is associated with an average productivity increase of $1-2$ percent.

The $R \& D$ research literature has also identified spillovers from $R \& D$. Thus, $R \& D$ undertaken in one firm can impact positively on value added in other firms in the same industry. Griffith et al. (2001) found that R\&D played a role in the convergence of TFP levels within industries across 12 OECD countries. Hence, R\&D stimulates growth both directly through innovation and indirectly through technology transfer. There is also a comprehensive literature investigating the spillover effects from public spending on $R \& D$ (Salter and Martin 2001; Goodridge et al. 2015). However, we will focus primarily on the direct effects of R\&D.

Until 2013 R\&D was not capitalized in the National Accounts, i.e., it was treated as a current expense. Since September 2014, when Statistics Sweden began to use the System of National Accounts 2008, R\&D is treated as investment (see SNA 2009). This strengthens the case for and facilitates the inclusion of R\&D when estimating production functions econometrically and estimating each input's contribution to economic growth based on the growth accounting framework.

In summary, the literature suggests that ICT capital has been an important source of economic and productivity growth at the aggregate, industry and firm-levels. Moreover, the same is true for $R \& D$; in addition to being a direct source of growth it also seems to stimulate growth through technology transfer. 


\section{Methodology}

\subsection{The standard neoclassical production function}

Our framework is based on the neoclassical production function model (Stiroh 2002b; 2005), where a gross output production function relates output to labor, capital, intermediate inputs and TFP: ${ }^{2}$

$$
Y_{i, t}=A_{i, t} f_{i, t}\left(K_{I C T, i, t}, K_{N, i, t}, R_{i, t}, L_{i, t}, M_{i, t}\right)
$$

where $Y_{i, t}$ is real gross output, $K_{I C T}$ is ICT related capital and $K_{N}$ is non-ICT capital, $R$ is R\&D capital, $L$ labor input, $M$ is intermediate input and $A$ is Hicks-neutral TFP, all for industry $i$ at time $t$. Assuming an augmented Cobb-Douglas production function, we get the following equation:

$$
Y_{i, t}=A_{i, t} K_{I C T, i, t}^{\beta_{I C T}} K_{N, i, t}^{\beta_{N}} R_{i, t}^{\beta_{R}} L_{i, t}^{\beta_{L}} M_{i, t}^{\beta_{M}}
$$

By taking natural logarithms of equation (2) we obtain the following expression:

$\ln Y_{i, t}=\beta_{I C T} \ln K_{I C T, i, t}+\beta_{N} \ln K_{N, i, t}+\beta_{R} \ln R_{i, t}+\beta_{L} \ln L_{i, t}+\beta_{M} \ln M_{i, t}+\ln A_{i, t}$

where $\beta$ represents the output elasticity of each input.

\subsection{Specification of the model}

The specification of the econometric model is based on the production function (section 3.1), but the dependent variable is value added rather than gross output. Value added is defined as gross output minus intermediate inputs, where gross output is defined as sales plus other operating income. There are both advantages and disadvantages with using either value added or gross output in production analyses (see section 4). We favor value added since it has the appealing property that nominal value added sums to GDP.

The specification is based on the standard augmented Cobb-Douglas production function. In addition to traditional capital it also includes R\&D capital. The specification can be written:

$$
\ln V_{i, t}=\beta_{I C T} \ln K_{I C T, i, t}+\beta_{N} \ln K_{N, i, t}+\beta_{R} \ln R_{i, t}+\beta_{L} \ln L_{i, t}+\delta_{t} D_{t}+\varepsilon_{i, t}
$$

\footnotetext{
${ }^{2}$ Value added is used instead of gross output to specify the model (see section 3.2). This implies that intermediate inputs are excluded as an independent variable.
} 
where $V_{i, t}$ is value added in industry $i$ at time $t, K_{I C T}$ is ICT capital, $K_{N}$ is non-ICT capital, $R$ is R\&D capital, and $L$ is labor input measured in hours. $D_{t}$ is a set of year dummy variables included in order to control for economic shocks. These time dummies take out the average variation over time and let us identify the production function parameters through the crosssectional variation. $\beta$ is the elasticity of the subscripted variables and $\varepsilon$ denotes serially uncorrelated random errors for each industry.

In addition to the specification in equation (4), it is also possible to divide ICT capital into hardware and software. The specification then becomes:

$$
\ln V_{i, t}=\beta_{S} \ln K_{S, i, t}+\beta_{H} \ln K_{H, i, t}+\beta_{N} \ln K_{N, i, t}+\beta_{R} \ln R_{i, t}+\beta_{L} \ln L_{i, t}+\delta_{t} D_{t}+\varepsilon_{i, t}
$$

where $K_{S, i, t}$ is software capital and $K_{H, i, t}$ is computer and communications hardware capital.

\section{Data}

The data used are based on the National Accounts provided by Statistics Sweden (2015) and cover 50 industries for the period 1993-2012. Table 1 presents the different industries following the international standard for industry classification (ISIC 2008). The following three industries had to be excluded due to missing data: Activities auxiliary to financial service insurance activities (ISIC K66), Real estate activities with own or leased property (ISIC 68A), and Health activities (ISIC P86). Thus, the regressions are based on 47 industries.

Output is measured as value added and labor input as hours worked. Value added estimates are based on double deflation and are expressed in real terms in prices of the year 1993, the initial year of the period examined. There are both advantages and disadvantages in using value added instead of gross output (Stiroh 2005). One advantage of using value added is that nominal value added sums to GDP. A disadvantage of value added is that one has to assume perfect competition (Basu and Fernald 1995). ${ }^{3}$

\footnotetext{
${ }^{3}$ Value added is defined as gross output minus intermediate inputs. This implies that one must know the marginal products of these intermediate inputs. Real value added is constructed assuming that these marginal products are observable from factor payments to intermediate goods. With imperfect competition the marginal
} 
Capital input data are based on estimates of capital services. Capital services are preferred to capital stock data, since the former accounts for the substitution between assets with different marginal products. As a result, the weights will not be too high for long lived assets such as industrial real estate. Statistics Sweden does not provide any official estimates of capital services for industries. Capital services were estimated based on data on investment, capital stock and investment price for the different industries provided by Statistics Sweden (using the methodology presented in Appendix A). Depreciation rates are from EU KLEMS (2011) and Statistics Sweden (see table 2)

ICT hardware includes both communications and computer equipment. According to EUKLEMS the depreciation rates between these differ. Statistics Sweden only publishes data for the aggregate of these two types of assets. Therefore, the depreciation rates in EU KLEMS have been weighted based on the average share of each type of capital in total gross fixed capital formation (GFCF), which implies that the depreciation rate for hardware is 16.1 percent while it is 31.5 percent for software. The data on GFCF for communications and computer equipment separately was made available by Statistics Sweden. Finally, the depreciation rate used for $R \& D$ has been set to 16.5 percent, which is close to the one used by Statistics Sweden. Table 2 shows the depreciation rates for each type of capital and industry.

Capital services were calculated for ICT, non-ICT and R\&D. Since 2014 R\&D is capitalized in the National Accounts. This makes it possible to use R\&D capital services when estimating production functions at the industry level. Moreover, ICT capital services were divided into the components hardware and software. Based on the calculations of capital services, indexes were constructed by using the capital stock in 1993 prices. A similar index was created for value added. ${ }^{4}$

Table 3 presents some descriptive statistics. It shows that the means of ICT and R\&D capital are considerably smaller than the mean of non-ICT capital. However, ICT capital is growing

product exceeds the factor payments. Thus, with imperfect competition value added can lead to spurious findings. On the other hand, contestable competition may suffice; the risk of entry may be enough to deter incumbents from exploiting their market power and maintain dynamic efficiency (Audretsch et al. 2001).

${ }^{4}$ The calculations of indexes for capital services and valued added were based on logarithmic changes. 
considerably faster on average compared to $\mathrm{R} \& \mathrm{D}$ and non-ICT capital. This is primarily due to high average growth of hardware capital.

\section{Results and Discussion}

\subsection{The basic model}

As argued by Stiroh (2002b), if one believes that the input choices are made before the productivity shocks, then pooled Ordinary Least Squares (OLS) estimators can be used to estimate equations (4) and (5). The results of these estimations are presented in table 4. For the regression based on ICT capital all coefficient are positive and highly significant. The estimated elasticity of ICT is 0.19 , which indicates a considerable effect from ICT. The ICT capital coefficient remains high also after controlling for economic shocks by introducing annual time dummies. On average, if ICT capital increases by 10 percent, value added increases by 1.8 percent. The estimated coefficient for $R \& D$ is $0.10-0.11$, not quite significant at the $5 \%$ level ( $p$-value $=0.06)$. The estimated coefficient for non-ICT capital is approximately 0.3 and highly significant.

When ICT is divided into hardware and software capital, the coefficients for all other independent variables remain highly significant and approximately unchanged. However, only software capital is significantly different from zero at an estimated elasticity of 0.22 and 0.23 , respectively. Hardware is not significantly different from zero. Thus, software capital is found to have a larger effect on value added than hardware. One possibility could be that investments in software capital are more closely associated with organizational changes raising value added. Yet, one should keep in mind that both software and hardware are necessary to reap the benefits of ICT investments. Thus, another possible explanation could be that all industries invest in hardware, but only the ones that successfully invest in and implement the right software enjoy a positive effect from ICT. This is further supported by the fact that the results are unaffected if hardware is excluded. Moreover, we would also expect small differences in investments in hardware across industries. Table 5 shows that the standard deviation of the logarithmic change in hardware capital within industries is larger than across industries, which provides further support for our hypothesis.

In table 4 we also present results based on weighted least squares (WLS), where value added weights in current prices are used. Stiroh (2005) argues that WLS is more appropriate 
because the variance of the residuals is inversely related to industry size. Thus, estimates based on WLS could potentially provide a better statistical representation of the economy as industries vary in size. However, the estimates are very similar to the OLS estimates. The coefficient for ICT capital becomes 0.17 instead of 0.18 and the coefficient for R\&D capital remains unchanged at 0.11 .

\subsection{Fixed effects and first differences}

The regressions presented so far have ignored unobservable industry-specific differences. In order to allow for these effects, it is possible to divide the error term into an industry-specific component and a classical error term:

$$
\ln V_{i, t}=\beta_{I C T} \ln K_{I C T, i, t}+\beta_{N} \ln K_{N, i, t}+\beta_{R} \ln R_{i, t}+\beta_{L} \ln L_{i, t}+\delta_{t} D_{t}+\left(\alpha_{i+} \varepsilon_{i, t}\right)
$$

where $\alpha_{i}$ is a set of unobserved industry-specific effects and $\varepsilon_{\mathrm{i}, \mathrm{t}}$ is the error term. The fixed effects model is based on the idea that productivity shocks vary across industries even further and allow for an industry-specific component that cannot be directly observed. A fixed effects model controls for or partials out the effects of these specific components.

The output elasticities can be estimated using different statistical techniques. We will use two methods. The first method is within-groups regression, where the mean values of the variables in the observations of a given industry are calculated and subtracted from the data of that industry. This removes the unobserved effect. The model explains the variation around the mean of the dependent variable in terms of the variations around the means of the explanatory variables for the group of observations for a given industry.

The second method takes the first difference of equation (8), which also removes the unobserved industry-specific effects. The following equation is estimated:

$$
\Delta \ln V_{i, t}=\beta_{I c t} \Delta \ln K_{I C T, i, t}+\beta_{N} \Delta \ln K_{N, i, t}+\beta_{R} \Delta \ln R_{i, t}+\beta_{L} \Delta \ln L_{i, t}+\delta_{t}+v_{i, t}
$$

where $\delta_{t}$ are year dummies, which capture common economic shocks, and $v_{i, t}$ is the differenced residual. 
Table 6 shows the results for the within groups method. The elasticity of ICT capital remains positive and significant at the 5 percent level when time-specific effects are not included. However, when time-specific effects are included to control for common economic shocks, the coefficient of ICT capital becomes insignificant. The same results are found based on first differences. Stiroh (2005) obtains similar results when using fixed effects methods on U.S. industry data for the period 1987-2000. He argues that the results could indicate an omitted variable that correlates with ICT, e.g., intangibles other than R\&D. Moreover, Griliches and Mairesse (1995) conclude that estimating production functions based on the fixed effects methodology often results in non-sensical results such as low and insignificants coefficients for capital and unreasonably low elasticity estimates that do not add up to 1, i.e., they do not exhibit constant returns to scale.

The elasticities of hours worked and R\&D remain significant at the 5 percent level when we control for industry and time-specific effects. The coefficients for R\&D are much larger compared to the estimates based on pooled OLS. The coefficients vary between 0.20 and 0.34 depending on the method used. Moreover, the coefficients for R\&D are significant at the 5 percent level with within-groups estimation, while they are significant at the 1 percent level based on first differences. Thus, $R \& D$ is more strongly associated with value added when industry-specific effects are taken into account.

Brynjolfsson and Hitt (2003) found that the returns of ICT increased when long-term differences were introduced. These findings were based on firm level data and the suggested interpretation was that the observed contribution of computerization would be accompanied by relatively large and time consuming investments in complementary inputs, notably organizational capital. However, when long differences of 5 and 10 years are used, based on our data, the ICT coefficient remains insignificant. Long differences entail a loss of information; the number of observation decreases by 20 and 45 percent, respectively, which greatly reduces the precision of the estimates.

\subsection{Interaction effects}

Section 5.2 showed that there was no significant effect from ICT based on fixed effects estimation including time dummies. One reason could be that we do not control for the quality of labor. A number of studies have pointed out that in order to realize the full 
potential of ICT, it is crucial to also invest in skills and education (Autor et al. 1998; O’Mahony and Peng 2011).

In order to control for the quality of labor we distinguish between the share of hours worked by low- and high-skilled employees in each industry, respectively. ${ }^{5}$ High-skilled employees are defined as employees with at least three years of university education. Unfortunately, data are only available for the period 2008-2012, due to changes in the industry classification. Moreover, it is assumed that all employees work the same number of hours. According to O’Mahony and Peng (2011) training and skills impact positively on productivity, especially when combined with investment in ICT. Therefore, we also allow for interaction effects between hours worked by low- and high-skilled employees and ICT capital. Thus, the following specification is used:

$\ln V_{i, t}=\beta_{L O W} \ln L_{L O W, i, t}+\beta_{H I G H} \ln L_{H I G H, i, t}+\beta_{I C T} \ln K_{I C T, i, t}+\beta_{N} \ln K_{N, i, t}+\beta_{R} \ln R_{i, t}+$ $+\beta_{\text {INTLOW }} \ln L_{L O W, i, t} \cdot \ln K_{I C T, i, t}+\beta_{\text {INTHIGH }} \ln L_{H I G H, i, t} \cdot \ln K_{I C T, i, t}+\delta_{t} D_{t}+\left(\alpha_{i+} \varepsilon_{i, t}\right)$

where $L_{L O W, i, t}$ and $L_{H I G H, i, t}$ are hours worked by low- and high-skilled employees and $\ln L_{L O W, i, t} \cdot \ln K_{I C T, i, t}$ and $\ln L_{H I G H, i, t} \cdot \ln K_{I C T, i, t}$ are the interaction terms for high- and low-skilled labor and ICT capital, respectively.

Table 7 presents the results based on different estimation techniques. Once we use our basic OLS and WLS models we get no significant coefficient except for non-ICT capital. However, when we use fixed effects estimation, we find that the high-skilled-ICT interaction term is significantly positive, while the low-skilled-ICT interaction term is significantly negative. Thus, high-skilled labor in combination with ICT investments is positively associated with value added.

\subsection{Discussion of simultaneity bias}

Simultaneity bias constitutes another potential problem with the estimations presented here. It arises when one or more of the explanatory variables are determined jointly with the dependent variable. Thus, it could be argued that firms make decisions on the volume of inputs partly based on their performance. One way of dealing with this problem is to use

${ }^{5}$ Due to lack of disaggregated data, the same skill share is applied for the following groups of industries: ISIC 26$28 ; 29-30 ; 49-53 ; 58-60$. 
instruments correlated with the inputs but uncorrelated with productivity shocks. Instruments that were used in previous studies are oil prices, defense spending shocks and monetary policy shocks (Basu et al. 2001; Stiroh 2005). However, we have not been able to find the corresponding data for these or any other reasonable instruments for Swedish industries.

Since there are no good instruments available, we tried to use internal instruments based on the Generalized Method of Moments (GMM). We ran regressions based on both Difference GMM (Arrelano and Bond 1991) and System GMM (Arellano and Bover 1995; Blundell and Bond 1998). However, it turned out that our industry data was insufficiently detailed to give any meaningful results, which is in line with the conclusion of Draca et al. (2006).

\subsection{The contribution of ICT and R\&D to aggregate growth}

Our results show that ICT and R\&D capital is associated with greater value added for most specifications based on industry-level data. However, it is not clear to what extent ICT and R\&D capital contribute to aggregate value added growth in the Swedish business sector. One way to estimate the contribution from ICT and R\&D is to use the growth accounting framework based on elasticities either from income shares or from econometric estimates. Growth accounting assesses the contribution of inputs to economic growth assuming constant returns to scale and that each factor receives compensation equal to its marginal productivity (Niebel et al. 2013). The relation can then be written:

$$
\Delta \ln V=s_{I C T} \Delta \ln K_{I C T}+s_{N} \Delta \ln K_{N}+s_{R} \Delta \ln R+s_{L} \Delta \ln L+\Delta \ln T F P
$$

where $V$ is aggregate value added, $K_{I C T}$ is ICT capital, $K_{N}$ is non-ICT capital, $R$ is R\&D capital, $L$ is labor input measured in hours, and TFP is total factor productivity measured as a residual.

Based on the assumptions of competitive markets and constant returns to scale it is possible to let the elasticities $\left(s_{I C T}, s_{N}, s_{R}, s_{L}\right)$ be equal to each factor's income share. When econometric estimation is used instead these assumptions are not necessary. Thus, unlike growth accounting, estimates based on econometric estimation show the contributions to growth from individual inputs as parameters rather than calculating them from income statistics. Moreover, the advantage of using industry data instead of firm level data is that the estimates are more likely to represent the average of the business sector as a whole. Firm 
level data are usually based on limited samples and are therefore likely to be less representative of the total business sector.

In general, if one believes that the input choices are made before the productivity shocks, then pooled OLS estimators can be trusted. In this paper, we have relaxed this assumption by using alternative estimation techniques. However, based on fixed effects estimation we did not find any significant coefficients for ICT and non-ICT capital. A closer examination showed that there were significant interaction effects of ICT and high-skilled labor based on fixed effects estimation, but not for pooled OLS. Moreover, regressions based on Difference GMM and System GMM did not provide any meaningful results as our industry data were insufficiently detailed.

In summary, our results suggest that there is strong evidence of an association between ICT investments and value added across industries. Moreover, our pooled OLS estimates are quite plausible from a theory of economic growth perspective, which suggests that input choices are made before productivity shocks. We therefore use output elasticities on either income shares or weighted least squares (WLS). ${ }^{6}$ A motivation for using WLS is that it provides a better representation of the aggregate business sector because industries vary in size and the classifications can be considered somewhat arbitrary (Stiroh 2005).

Figure 2 shows the contribution from each input based on the growth accounting methodology in 1993-2012. When output elasticities are based on WLS estimation instead of income shares, the contribution of ICT to value added growth increases from 0.9 to 1.5 percentage points. The reason for this large difference is that the ICT elasticity estimates are larger than the factor share of ICT in total income, which is on average approximately 0.10 for the investigated period.

Based on the assumptions of competitive input markets (each input is paid its marginal product) and input exhaustion (all revenue is paid to factors) an input's factor share is equal to the elasticity (Stiroh 2002b). However, our estimated elasticity is 70 percent higher than the share of ICT in total income, if we use the estimated elasticity coefficient of 0.17 . This could reflect excess returns indicating that the marginal return of ICT outweighs marginal

\footnotetext{
${ }^{6}$ The output elasticites based on WLS estimations include time dummies.
} 
cost (Stiroh 2005). This raises the question why there is not even more investment in ICT. One possibility is that there is lack of information about the potential benefits for firms to invest in ICT, while another could be market regulations. A third possibility is that there is an omitted variable bias. Examples of omitted inputs that could be correlated with ICT are other intangibles such as vocational training and organizational capital. Complementary investments in new business processes, new skills and new organizational and industrystructures are often necessary in order to get a high rate of return on ICT investments, both at the firm and aggregate level (Brynjolfsson and Hitt 2000).

Figure 2 also shows that the contribution from R\&D increases marginally from 0.36 to 0.43 percentage points when output elasticities are based on WLS estimation. The relative contribution by hours worked and non-ICT capital decreases slightly when output shares are based on WLS estimation rather than on income shares.

In summary, ICT and R\&D together account for 1.2 percentage points of value added growth in the Swedish business sector in 1993-2012 based on income shares, while the corresponding figure is 1.9 percentage points based on WLS estimation of output elasticities. Depending on the method used to estimate output elasticities, this implies that ICT and R\&D account for either 36 or 58 percent of total value added growth in the Swedish business sector. Thus, ICT and R\&D investments have been prime drivers of growth in the business sector since the mid-1990s.

\section{Sensitivity Analysis}

Table 8 presents a sensitivity analysis of the OLS and WLS estimates. We begin by dropping ICT producing industries. Value added and productivity growth has been particularly high in computer, electronic and optical products (ISIC C26) (Edquist and Henrekson 2006), which could potentially bias the results. However, the ICT coefficient is unaffected when ICT producing industries are dropped, while the R\&D coefficient decreases and becomes less significant.

We then check robustness by splitting the regressions into three different time periods: 19932000, 2001-2007 and 2008-2012. According to Jorgenson et al. (2008) productivity growth in the U.S. economy during the second half of the 1990s was driven both by productivity 
growth in the ICT producing industries and by the massive ICT investments in the ICT using industries. However, after the 2000-2001 dot.com crash productivity growth primarily took place outside of the ICT producing industries (Jorgenson et al. 2008). This motivates the choice of the first two periods. The third period examines the development after the global financial crisis starting in 2008. The estimate of ICT capital remains robust to the disaggregation into the three time periods. The coefficients for $R \& D$ are positive and generally higher in the last two periods. The significance level was generally higher for R\&D in 2001-2007.

Finally, table 8 presents the coefficients for ICT and R\&D when the sample is divided into manufacturing and services. The results show that the coefficients for ICT and R\&D are higher in manufacturing compared to services. However, even if the ICT coefficient is clearly larger in manufacturing it is still significant at the 5 percent level for services. Moreover, the R\&D coefficient is highly significant for manufacturing, but insignificant for services. Thus, R\&D is less associated with value added in services compared to manufacturing.

In section 5.4, the elasticities estimated by weighted least squares (WLS) were used in a growth accounting framework to estimate the impact on total growth by ICT and R\&D. It was argued that the estimates based on WLS would be most representative for the total business sector because industries vary in size and the classifications can be considered somewhat arbitrary. Figure 3 shows the total contribution from ICT and R\&D based on elasticities estimated in three different ways (based on specifications where both the estimated coefficients of ICT and R\&D are significant at the 10 percent level or higher).

The estimated contribution from ICT becomes greater when econometric estimates are used instead of income shares. Moreover, the estimated contribution from R\&D becomes considerably greater when elasticities are based on fixed effects estimates excluding time dummies. Even though there is some variation depending on the method used to estimate output elasticities, it is safe to conclude that both ICT and R\&D investments have been important drivers of value added growth in the Swedish business sector in recent decades. 


\section{Conclusions}

From the mid-1990s until recently both productivity growth and GDP growth was rapid in Sweden. Particularly the business sector experienced high rates of growth. The annual value added growth was 3.4 percent, which is also high compared to many other OECD-countries. Explaining with precision to what extent different factors have contributed to this development is no easy task.

ICT and R\&D have been identified as important drivers of economic growth. In the last 20 years Sweden has experienced a revolution in ICT. For example, in the 1990s the number of mobile phone subscriptions and the use of Internet increased rapidly, and today the Internet is to a large extent mobile. Manufacturing of computer, electronic and optical products (ISIC $\mathrm{C} 26)$ is also the industry that has invested the most in $\mathrm{R} \& \mathrm{D}$ in recent years.

We estimate output elasticities of ICT, R\&D and other inputs based on econometric estimation of the neoclassical production function. We show that ICT and R\&D capital is associated with greater value added for most specifications. Controlling for both economic shocks and the fact that the variance is often larger for small industries, the coefficient for ICT capital is 0.17 . Thus, an increase of ICT capital by 10 percent is associated with a 1.7 percent increase in value added.

When ICT capital is divided into hardware and software, only software is significantly associated with value added. To our knowledge this distinction has not been made in any previous study at the industry level. One possible explanation could be that all industries invest in hardware, but only the ones that successfully invest in and implement software enjoy positive effects from ICT. This hypothesis is further supported by the fact that the standard deviation of the logarithmic change in hardware capital is larger within than across industries. The estimated elasticity for R\&D capital based on weighted least squares in the pooled regressions is 0.11 , but it is only significant at the 10 percent level $(p$-value $=0.06)$.

When fixed effects estimation is used the ICT coefficient remains significant at the 5 percent level. However, when both fixed effects and time dummies are included in the regression the ICT coefficient becomes insignificant. One reason could be that there are omitted variables that correlate with ICT. Similar results are found for the U.S. Moreover, based on fixed 
effects estimation techniques, we find positive interaction effects between hours worked by high-skilled employees and ICT and negative interaction effects between hours worked by low-skilled employees and ICT. Thus, high-skilled labor in combination with ICT investments is positively associated with value added. Furthermore, R\&D capital is strongly associated with value added when we control for industry-specific effects.

Finally, we use the growth accounting framework to compare the contribution of inputs when output elasticities are based on income shares and WLS estimations, respectively. When output elasticities are based on WLS instead of income shares, the contribution of ICT to value added growth increases from 0.9 to 1.5 percentage points. Possible explanations to the differences are excess returns, lack of information, market regulations and omitted variable bias.

In summary, our results show that both ICT and R\&D capital are positively associated with value added in the Swedish non-farm business sector. The estimated coefficients are large and significant for most specifications. Moreover, ICT and R\&D accounted for 36 or 58 percent of value added growth depending on whether output elasticities were based on income shares or WLS estimations. Thus, it can be concluded that the growth contribution of ICT and R\&D investments has been substantial. Our results also suggest that countries with an industry structure similar to that of Sweden could benefit from developing or strengthening institutions that encourage investments in ICT and R\&D. 


\section{Appendix A: Capital Services}

There are different types of capital such as buildings, vehicles and software. Statistics

Sweden publishes figures for these different types of capital in terms of capital stocks.

However, using capital stocks when analyzing the impact of capital is likely to be

misleading, since long-lived types of capital, such as buildings, get too high a weight compared to short-lived assets, such as software. According to Jorgenson and Griliches (1967) the theoretically correct way to measure capital in a production function is by measuring capital services. These services can be estimated by the rental payments that a profit maximizing firm would pay when renting its capital.

In order to estimate capital services it is necessary to estimate the capital stock. We estimate the capital stock based on the perpetual inventory method (PIM). ${ }^{7}$ The different types of capital included in the calculations are: Dwellings, other buildings, transportation equipment, ICT hardware, other machinery and equipment and weapon systems, research and development and software. ${ }^{8}$

By assuming a geometric depreciation pattern the capital stock (K), for each type of capital $(s)$ at time $(t)$, can be derived according to the following formula: ${ }^{9}$

$$
K_{s, t}=\left(1-\delta_{s, t}\right) K_{s, t-1}+I_{s, t}
$$

where $K_{s, t}$ is the capital stock, $\delta_{s, t}$ is the depreciation rate and $I_{s, t}$ is real investment. Depreciation rates are from the EU KLEMS database (EU KLEMS 2011). The industry structure in EU KLEMS differs somewhat from the classification used by Statistics Sweden (i.e. ISIC rev. 4). Thus, for a few industries that are not included in EU KLEMS approximations were made. Table 2 shows the depreciation rates used for each type of capital and industry.

Based on the estimates of the capital stocks and investment price indexes $\left(p^{I}\right)$ provided by Statistics Sweden it is possible to calculate the internal rate of return for each industry $i$ :

\footnotetext{
${ }^{7}$ For a detailed description, see OECD (2009b).

${ }^{8}$ The capital stocks of (1) Cultivated biological resources and (2) Other intellectual property products were excluded. These two types of capital only accounted for 0.7 percent of total investments in 2012.

${ }^{9}$ The initial base year is 1993 , where the estimates of the level of the capital stocks are provided by Statistics Sweden (2015).
} 


$$
\operatorname{irr}_{i, t}=\frac{p_{t}^{K} K_{t}+\sum_{s}\left(p_{s, i, t}^{I}-p_{s, i, t-1}^{I}\right) K_{s, i, t}-\sum_{s} p_{s, i, t}^{I} \delta_{s, i, t} K_{s, i, t}}{\sum_{s} p_{s, i, t-1}^{I} K_{s, i, t}}
$$

where the first term $p_{t}^{K} K_{t}$ denotes overall capital compensation in the economy. By assuming constant returns to scale it can be estimated as value added in current prices minus labor compensation. $p_{s, i, t}^{I}$ is the investment price of capital $s$ in industry $i$ at time $t, K_{s, i, t}$ is the capital stock, and $\delta_{s, i, t}$ is the depreciation rate. The internal rate of return varies across industries but not across types of capital $(s)$, as the internal rate of return will be equalized across assets in a competitive market.

The internal rate of return $\left(i r r_{i, t}\right)$ is then used to derive the rental prices $\left(p_{s, i, t}^{K}\right)$ of each capital type $(s)$ in industry $i$. The rental price equals the price at which the investor is indifferent between buying and renting the capital good in the rental market. The rental price can be estimated as follows:

$$
p_{s, i, t}^{K}=p_{s, i, t-1}^{I} \operatorname{irr}_{i, t}+\delta_{s, i, t} p_{s . i, t}^{I}-\left(p_{s, i, t}^{I}-p_{s, i, t-1}^{I}\right)
$$

where $\operatorname{irr}_{i, t}$ is the internal rate of return, $\delta_{s, i, t}$ is the depreciation rate and $p_{s, i, t}^{I}$ is the investment price of asset $s$. Thus, eq. (A.3) shows that the rental price is determined by the nominal rate of return, the rate of economic depreciation and the asset-specific capital gain.

Rental prices can be used to calculate capital compensation for each type of capital and industry:

$$
c_{s, i, t}=p_{s, i, t}^{K} K_{s, i, t}
$$

Finally, the change in capital services for industry $i$ is obtained as follows:

$$
\Delta \ln K_{i, t}=\sum_{s} \tilde{v}_{s, i, t} \Delta \ln K_{s, i, t}
$$

where the weight $\tilde{v}_{s, i, t}$ is the two-period average share of compensation by each type of capital in the total value of capital compensation for all industries: 


$$
\begin{aligned}
& \tilde{v}_{s, i, t}=\frac{1}{2}\left(v_{s, i, t}+v_{s, i, t-1}\right) \\
& v_{s, i, t}=\frac{C_{s, i, t}}{\sum_{s} C_{s, i, t}}
\end{aligned}
$$

This method is used to calculate capital services for ICT capital and non-ICT capital and R\&D. 


\section{References}

Arrelano, Manuel, and Bond, Stephen (1991), "Some Tests of Specification for Panel Data: Monte Carlo Evidence and Application to Employment Equations", Review of Economic Studies, vol. 58, pp. 277-297.

Arrelano, Manuel, and Bover, Olympia (1995), "Another Look at the Instrumental Variable Estimation of Error-Components Models", Journal of Econometrics, vol. 68, pp. 29-51.

Audretsch, David B., Baumol, William J., and Burke, Andrew E. (2001), "Competition Policy in Dynamic Markets", International Journal of Industrial Organization 19(5), 613-634.

Autor, David H, Katz, Lawrence F., and Krueger, Alan B. (1998), "Computing Inequality: Have Computers Changed the Labour Market?”, Quarterly Journal of Economics, vol. 113, pp. 1169-1213.

Basu, Susanto, and Fernald, John G. (1995), “Are Apparent Productive Spillovers a Figment of Specification Error”, NBER Working Paper No. 5073. Cambridge, MA: National Bureau of Economic Research.

Basu, Susanto, Fernald, John G., and Shapiro, Matthew, D. (2001), "Productivity Growth in the 1990s: Technology, Utilization, or Adjustment?”, NBER Working Paper No. 8359. Cambridge, MA: National Bureau of Economic Research.

Basu, Susanto, and Fernald, John G. (2007), "Information and Communications Technology as a General-Purpose Technology: Evidence from U.S. Industry Data", German Economic Review, vol. 8, pp. 79-93.

Blundell, Richard, and Bond, Stephen (1998), "Initial Conditions and Moment Restrictions in a Dynamic Panel Data Model”, Journal of Econometrics, vol. 87, pp. 115-143.

Brynjolfsson, Erik, and Hitt, Lorin M. (2000), "Beyond Computation: Information Technology, Organizational Transformation and Business Performance", Journal of Economic Perspectives, vol. 14, pp. 23-48.

Brynjolfsson, Erik, and Hitt, Lorin M. (2003), "Computing Productivity: Firm level Evidence", Review of Economics and Statistics, vol. 85, pp. 793-808.

Brynjolfsson, Erik, and McAfee, Andrew (2014), The Second Machine Age: Work, Progress and Prosperity in a Time of Brilliant Technologies, W.W. Norton \& Company, New York.

Byrne, David M., Oliner, Stephen, and Sichel, Daniel E. (2013), "Is the Information Technology Revolution Over?”, FEDS Working Paper, Federal Reserve Board, Washington, D.C.

Chen, Wen, Niebel, Thomas, and Saam, Marianne (2016), "Are Intangibles More Productive in ICT-Intensive Industries? Evidence from EU Countries”, Telecommunications Policy, vol. 40, pp. 471-484.

Corrado, Carol, Hulten, Charles, and Sichel, Daniel (2009), "Intangible Capital and U.S. Economic Growth", Review of Income and Wealth, vol. 55, pp. 661-685.

Corrado, Carol, Haskel, Jonathan, and Jona-Lasinio, Cecilia (2014), "Knowledge Spillovers, ICT and Productivity Growth", IZA Discussion Paper No. 8274, Institute of Labor Economics, Bonn.

Dahl, Christian, Kongsted, Hans Christian, and Sørensen, Anders (2010), "ICT and Productivity Growth in the 1990s: Panel Data Evidence on Europe", Empirical Economics, vol. 40, pp. 141-164. 
Draca, Mirko, Sadun, Raffaella, and Van Reenen, John (2006), "Productivity and ICT: A Review of the Evidence", CEP Discussion Paper No. 749. London: London School of Economics.

Edquist, Harald (2011), "Can Investment in Intangibles Explain the Swedish Productivity Boom in the 1990s", Review of Income and Wealth, vol. 57, pp. 658-682.

Edquist, Harald, and Henrekson, Magnus (2006), "Technological Breakthroughs and Productivity Growth" Research in Economic History, vol. 24, pp. 1-53.

EU KLEMS (2011), EU KLEMS Growth and Productivity Accounts, November 2009 Release, updated March 2011.

Goodridge, Peter, Haskel, Jonathan, Hughes, Alan, and Wallis, Gavin (2015), "The Contribution of Public and Private R\&D to UK Productivity Growth", Discussion Paper 2015/03, Imperial College, London.

Gordon, Robert J. (2000), "Does the 'New Economy' Measure up to the Great Inventions of the Past?", Journal of Economic Perspectives, vol. 14, pp. 49-74.

Griffith, Rachel, Redding, Stephen, and Van Reenen, John (2001) "Mapping the Two Faces of R\&D: Productivity Growth in a Panel of OECD Industries", IFS Working Paper W02/00, Institute for Fiscal Studies, London.

Griliches, Zvi (1991), “The Search for R\&D Spillovers”, NBER Working Paper No. 3768. Cambridge, MA: National Bureau of Economic Research.

Griliches, Zvi, and Mairesse, Jacques (1995), "Production Functions: The Search for Identification”, NBER Working Paper No. 5067. Cambridge, MA: National Bureau of Economic Research.

Gruber, Harald, and Koutroumpis, Pantelis (2011), "Mobile Telecommunications and the Impact on Economic Development", Economic Policy, vol. 26, pp. 387-426.

Gust, Christopher, and Marques, Jamie (2004), "International Comparisons of Productivity Growth: The Role of Information Technology and Regulatory Practice”, Labour Economics, vol. 11, pp. 33-58.

Hall, Bronwyn H., Mairesse, Jacques, and Mohnen, Pierre (2009), "Measuring the Returns to R\&D”, NBER Working Paper No. 15622, Cambridge, MA: National Bureau of Economic Research.

ISIC (2008), "International Standard Industrial Classification of All Economic Activities (ISIC), Rev 4, Statistics Revision. New York: United Nations.

Jorgenson, Dale W., and Griliches, Zvi (1967), "The Explanation of Productivity Change", Review of Economic Studies, vol. 34, pp. 349-383.

Jorgenson, Dale W., Ho, Mun S., and Stiroh, Kevin J. (2008), “A Retrospective Look at the U.S. Productivity Growth Resurgence”, Journal of Economic Perspectives, vol. 22, pp. 3-24.

Marrano, Mauro G., Haskel, Jonathan, and Wallis, Gavin (2009), What Happened to the Knowledge Economy? ICT, Intangible Investment and Britain's Productivity Record Revisited", Review of Income and Wealth, vol. 55, pp. 686-716.

McMorrow, Kieran, and Röger, Werner (2009), "R\&D Capital and Economic Growth: The Empirical Evidence”, EIP Papers, vol. 14, pp. 94-118.

Nelson, Richard R. (1959), "The Simple Economics of Basic Scientific Research”, Journal of Political Economy, vol. 67, pp. 297-306.

Niebel, Thomas, O’Mahony, Mary, and Saam, Marianne (2013), "The Contribution of Intangible Assets to Sectoral Productivity Growth in the EU", Discussion Paper No. 13062. Mannheim: Zentrum für Europäische Wirtschaftsforschung (ZEW). 
Niebel, Thomas (2014), "ICT and Economic Growth - Comparing Developing, Emerging and Developed Countries", paper presented at the $33^{\text {rd }}$ IARIW General conference, Rotterdam.

OECD (2002), Frescati Manual: Proposed Standard Practice for Surveys on Research and Experimental Development. Paris: OECD.

OECD (2009a), Guide to Measuring the Information Society 2009. Paris: OECD.

OECD (2009b), Measuring Capital - OECD Manual 2009. Paris: OECD.

OECD (2015a), Gross Domestic Spending on R\&D (Indicator), doi: 10.1787/d8b068b4-en (Accessed on 19 April 2015). Paris: OECD.

OECD (2015b), ICT investment (Indicator), doi: 10.1787/b23ec1da-en (Accessed on 17 April 2015). Paris: OECD.

OECD (2017), STAN Database for Structural Analysis (ISIC Rev. 4). Paris: OECD.

Oliner, Stephen D., and Sichel, Daniel (2000), "The Resurgence of Growth in the Late 1990s: Is Information Technology the Story?", Journal of Economic Perspectives, vol. 14, pp. 3-22.

O’Mahony, Mary, and Vecchi, Michaela (2005), "Quantifying the Impact of ICT Capital on Output Growth: A Heterogeneous Dynamic Panel Approach”, Economica, vol. 91, pp. 909-923.

O’Mahony, Mary, and Peng, Fei (2011), "Intangible Training Capital and Productivity in Europe", MPRA Paper No. 38648, Munich.

Röller, Lars-Hendrik, and Waverman, Leonard (2001), “Telecommunications Infrastructure and Economic Development: A Simultaneous Approach", American Economic Review, vol. 91, pp. 909-923.

Salter, Ammon J., and Martin, Ben R. (2001), “The Economic Benefits of Publicly Funded Basic Research: A Critical View", Research Policy, vol. 30, pp. 509-532.

Schumpeter, Joseph A. (1942/1966), Capitalism, Socialism and Democracy. London: Unwin University Books.

SNA (2009), System of National Accounts 2008, European Commission, IMF, OECD, UN, World Bank, New York.

Solow, Robert M. (1987), "We'd Better Watch Out”, New York Review of Books, July 12, p. 36.

Spiezia, Vincenzo (2012), "ICT-Investments and Productivity: Measuring the Contribution of ICTs to Growth", OECD Journal: Economic Studies, vol. 2012/1. Paris: OECD.

Statistics Sweden (2015), Nationalräkenskaper, kvartals- och årsberäkningar, http://www.scb.se.

Stiroh, Kevin J. (2002a), "Information Technology and the U.S. Productivity Revival: What Do the Industry Data Say?", American Economic Review, vol. 92, pp. 1559-1576.

Stiroh, Kevin J. (2002b), “Are ICT Spillovers Driving the New Economy?”, Review of Income and Wealth, vol. 48, pp. 33-57.

Stiroh, Kevin J. (2005), "Reassessing the Impact of IT in the Production Function: A MetaAnalysis and Sensitivity Tests", Annales d'Économie et de Statistique, No. 79/80, pp. 529-561.

van Ark, Bart, O’Mahony, Mary, and Timmer, Marcel (2008), "The Productivity Gap between Europe and the United States: Trends and Causes", Journal of Economic Perspectives, vol. 22, pp. 25-44. 
Van Reenen, John, Bloom, Nicholas, Draca, Mirko, Kretschmer, Tobias, Sadun, Raffaella, Overman, Henry, and Shankerman, Mark (2010), “The Economic Impact of ICT”, Centre for Economic Performance, London School of Economics, London.

\section{Acknowledgements}

We are grateful for useful comments and suggestions by, Mikael Anneroth, Wen Chen, Craig Donovan, Mary O'Mahony, Christer Törnevik and the participants at our presentation at the $34^{\text {th }}$ IARIW General Conference, Dresden 21-27 August 2016. Magnus Henrekson also gratefully acknowledges financial support from the Jan Wallander and Tom Hedelius Foundation and the Marianne and Marcus Wallenberg Foundation. 


\section{Figures and tables}

Figure 1 Average annual value added growth in the non-farm business sector in sixteen OECD countries, 1995-2015

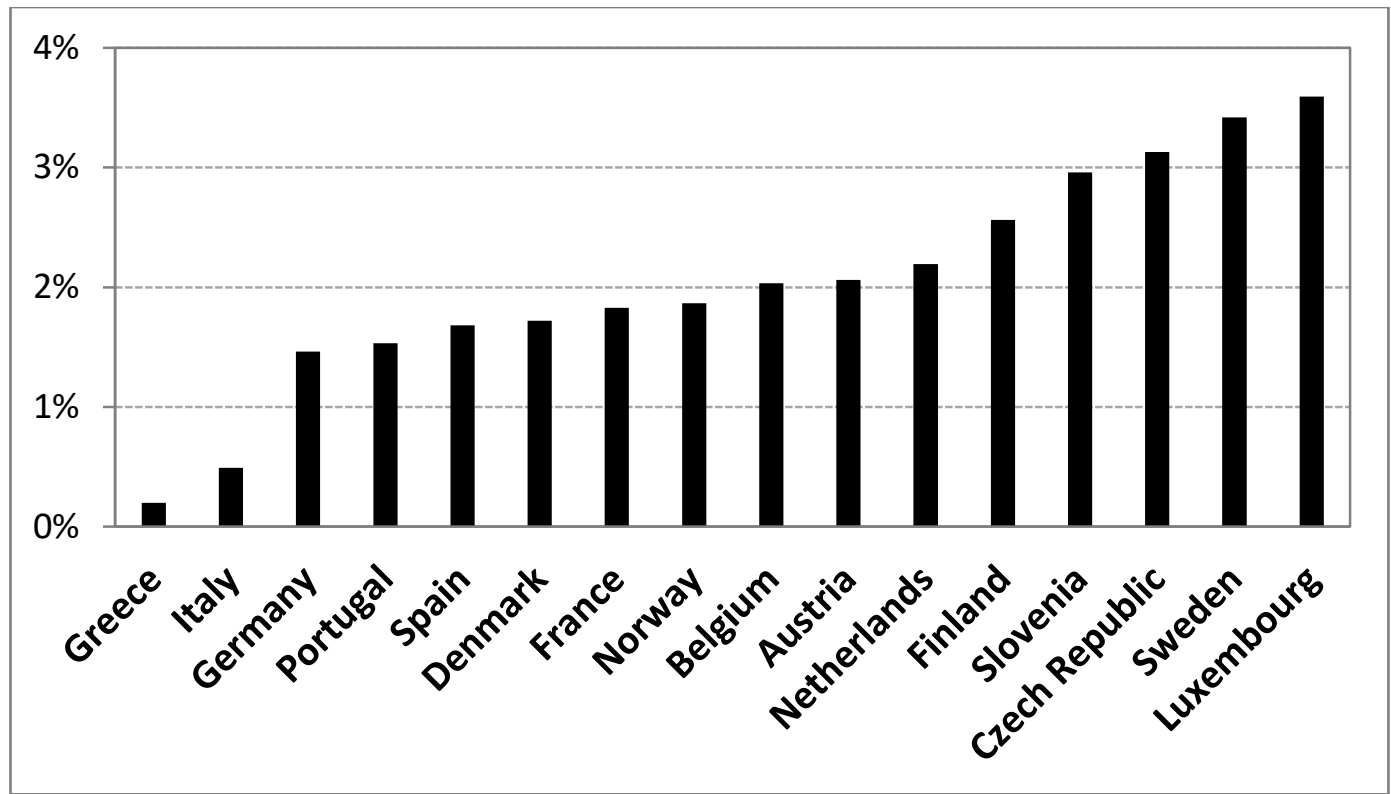

Note: Countries have been included based on data availability. Data is based on industry classifications according to ISIC rev. 4 and real estate activities are excluded.

Source: OECD (2017).

Figure 2 Growth accounting for the Swedish non-farm business sector in 1993-2012, based on income shares and WLS estimates of output elasticities

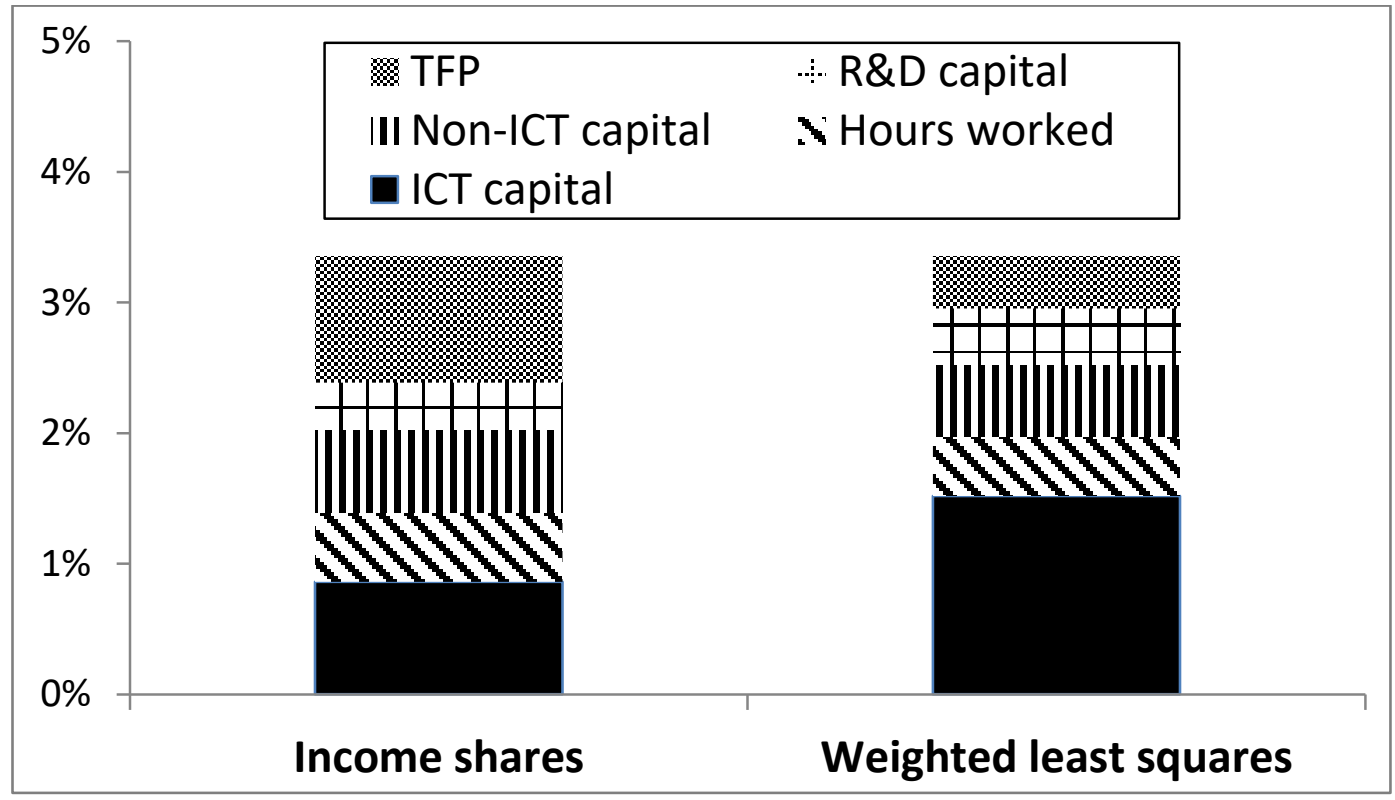

Source: Statistics Sweden (2015) and own calculations. 
Figure 3 Contribution from ICT and R\&D based on the growth accounting framework with different estimates of output elasticities

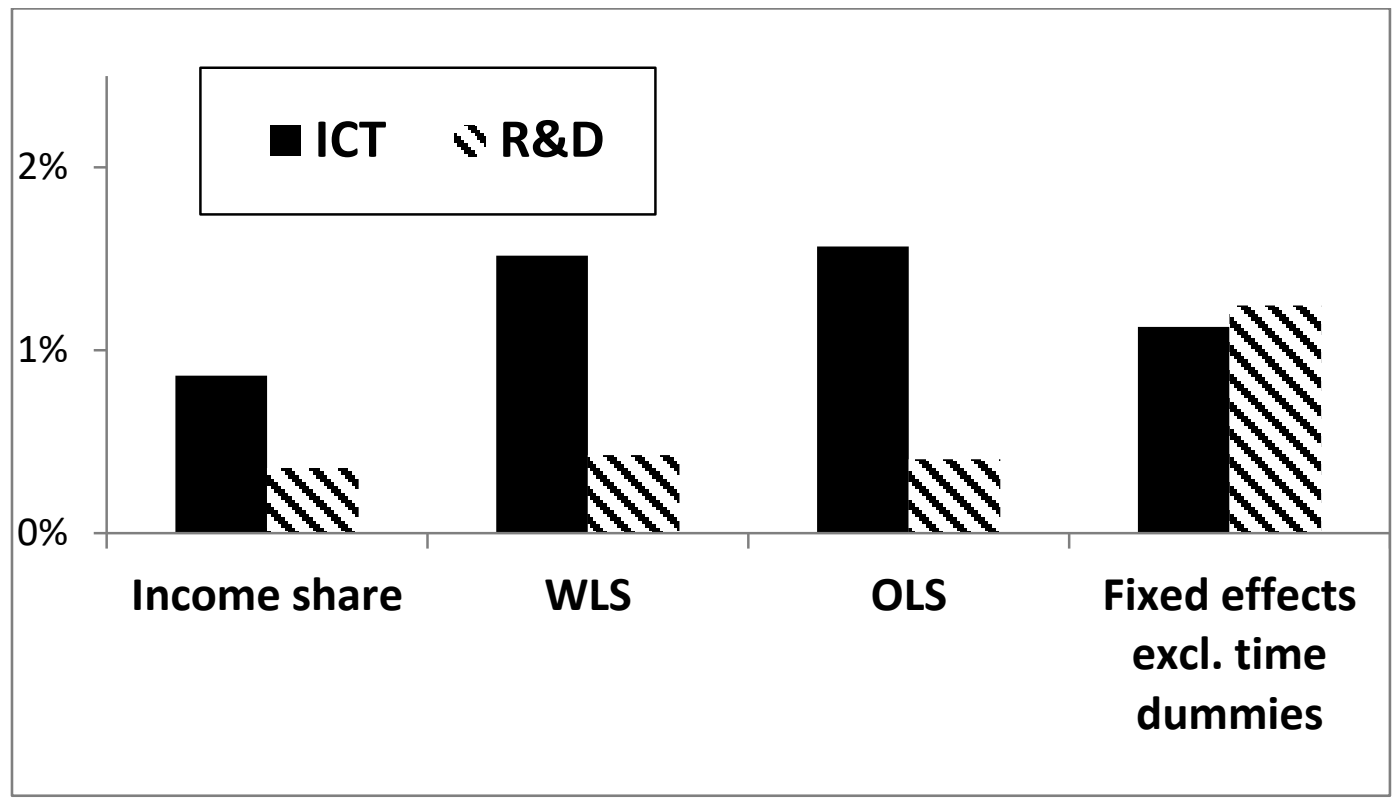

Source: Statistics Sweden (2015) and own calculations. 
Table 1 List of industries included in the regression analysis

\begin{tabular}{|c|c|}
\hline Industry & ISIC Rev.4 \\
\hline Mineral extract & B05-09 \\
\hline Food & $\mathrm{C} 10-\mathrm{C} 12$ \\
\hline Textile, clothing and leather products & $\mathrm{C} 13-\mathrm{C} 15$ \\
\hline Wood and wood products & $\mathrm{C} 16$ \\
\hline Paper and paper products & $\mathrm{C} 17$ \\
\hline Printing and reproduction of recorded media & $\mathrm{C} 18$ \\
\hline Coke and refined petroleum products & $\mathrm{C} 19$ \\
\hline Chemical, chemical products and pharmaceutical products & $\mathrm{C} 20-\mathrm{C} 21$ \\
\hline Rubber and plastic products & $\mathrm{C} 22$ \\
\hline Non-metallic mineral products & $\mathrm{C} 23$ \\
\hline Basic metals & $\mathrm{C} 24$ \\
\hline Fabricated metal products except machinery and equipment & $\mathrm{C} 25$ \\
\hline Computer, electronic and optical products & $\mathrm{C} 26$ \\
\hline Electrical equipment & $\mathrm{C} 27$ \\
\hline Machinery and equipment & $\mathrm{C} 28$ \\
\hline Motor vehicles, trailers and semi-trailers & $\mathrm{C} 29$ \\
\hline Other transportation equipment & $\mathrm{C} 30$ \\
\hline Furniture and other manufacturing & $\mathrm{C} 31-\mathrm{C} 32$ \\
\hline Repair and installation of machinery and equipment & C33 \\
\hline Electricity, gas and steam & D35 \\
\hline Water collection and sewerage & E36-E37 \\
\hline Waste collection, materials recovery and remediation & E38-E39 \\
\hline Construction & F41-F43 \\
\hline Wholesale and retail trade of motor vehicles and motorcycles & G45 \\
\hline Wholesale trade except of motor vehicles and motorcycles & G46 \\
\hline Retail trade except of motor vehicles and motorcycles & G47 \\
\hline Land transport and transport via pipelines & $\mathrm{H} 49$ \\
\hline Water transport & $\mathrm{H} 50$ \\
\hline Air transport & H51 \\
\hline Warehousing and postal and courier activities & H52-H53 \\
\hline Hotels and restaurants & H55-H56 \\
\hline Publishing activities & $\mathrm{J} 58$ \\
\hline Motion picture, programming and broadcasting & J59-J60 \\
\hline Telecommunications & J61 \\
\hline Computer programming and related activities and information services & J62-J63 \\
\hline Financial service activities & K64 \\
\hline Insurance, reinsurance and pension funding & K65 \\
\hline Activities auxiliary to financial service and insurance activities & K66 \\
\hline Real estate activities with own or leased property & L68A \\
\hline Other real estate activities & L68B \\
\hline Legal and accounting activities and management consulting & M69-M70 \\
\hline $\begin{array}{l}\text { Architectural and engineering activities and scientific research and } \\
\text { development }\end{array}$ & M71-M72 \\
\hline Advertising, market research and veterinary activities & M73-M75 \\
\hline Rental and leasing activities & N77 \\
\hline Administrative and support service activities & N78-N82 \\
\hline Education & P85 \\
\hline Health activities & P86 \\
\hline Human health activities & Q87-Q88 \\
\hline Arts, entertainment and recreation & R90-R93 \\
\hline Other service activities and activities of households as employers & S94-T98 \\
\hline
\end{tabular}

Source: ISIC (2008). 
Table 2 Depreciation rates used for each type of capital and industry

\begin{tabular}{|c|c|c|c|c|c|c|c|}
\hline ISIC Rev.4 & Dwellings & $\begin{array}{c}\begin{array}{c}\text { Other } \\
\text { buildings }\end{array} \\
\end{array}$ & $\begin{array}{c}\text { Transport } \\
\text { equip }\end{array}$ & $\begin{array}{c}\text { ICT } \\
\text { hardware }\end{array}$ & $\begin{array}{c}\text { Other } \\
\text { machine }\end{array}$ & R\&D & $\begin{array}{c}\text { ICT } \\
\text { software } \\
\end{array}$ \\
\hline B05-09 & 0.011 & 0.024 & 0.170 & 0.161 & 0.129 & 0.165 & 0.315 \\
\hline $\mathrm{C} 10-\mathrm{C} 12$ & 0.011 & 0.033 & 0.168 & 0.161 & 0.109 & 0.165 & 0.315 \\
\hline C13-C15 & 0.011 & 0.033 & 0.184 & 0.161 & 0.109 & 0.165 & 0.315 \\
\hline C16 & 0.011 & 0.032 & 0.183 & 0.161 & 0.109 & 0.165 & 0.315 \\
\hline $\mathrm{C} 17$ & 0.011 & 0.033 & 0.173 & 0.161 & 0.106 & 0.165 & 0.315 \\
\hline $\mathrm{C} 18$ & 0.011 & 0.033 & 0.173 & 0.161 & 0.106 & 0.165 & 0.315 \\
\hline C19 & 0.011 & 0.032 & 0.154 & 0.161 & 0.110 & 0.165 & 0.315 \\
\hline $\mathrm{C} 20-\mathrm{C} 21$ & 0.011 & 0.033 & 0.181 & 0.161 & 0.104 & 0.165 & 0.315 \\
\hline $\mathrm{C} 22$ & 0.011 & 0.033 & 0.202 & 0.161 & 0.113 & 0.165 & 0.315 \\
\hline $\mathrm{C} 23$ & 0.011 & 0.033 & 0.191 & 0.161 & 0.112 & 0.165 & 0.315 \\
\hline $\mathrm{C} 24$ & 0.011 & 0.033 & 0.169 & 0.161 & 0.106 & 0.165 & 0.315 \\
\hline $\mathrm{C} 25$ & 0.011 & 0.033 & 0.169 & 0.161 & 0.106 & 0.165 & 0.315 \\
\hline $\mathrm{C} 26$ & 0.011 & 0.033 & 0.166 & 0.161 & 0.108 & 0.165 & 0.315 \\
\hline $\mathrm{C} 27$ & 0.011 & 0.033 & 0,166 & 0.161 & 0.108 & 0.165 & 0.315 \\
\hline $\mathrm{C} 28$ & 0.011 & 0.033 & 0.170 & 0.161 & 0.107 & 0.165 & 0.315 \\
\hline C29 & 0.011 & 0.033 & 0.167 & 0.161 & 0.109 & 0.165 & 0.315 \\
\hline C30 & 0.011 & 0.033 & 0.167 & 0.161 & 0.109 & 0.165 & 0.315 \\
\hline C31-C32 & 0.011 & 0.033 & 0.193 & 0.161 & 0.113 & 0.165 & 0.315 \\
\hline C33 & 0.011 & 0.033 & 0.193 & 0.161 & 0.113 & 0.165 & 0.315 \\
\hline DD35 & 0.011 & 0.023 & 0.191 & 0.161 & 0.094 & 0.165 & 0.315 \\
\hline E36-E37 & 0.011 & 0.023 & 0.191 & 0.161 & 0.094 & 0.165 & 0.315 \\
\hline E38-E39 & 0.011 & 0.023 & 0.191 & 0.161 & 0.094 & 0.165 & 0.315 \\
\hline F41-F43 & 0.011 & 0.034 & 0.195 & 0.161 & 0.139 & 0.165 & 0.315 \\
\hline G45 & 0.011 & 0.031 & 0.229 & 0.161 & 0.121 & 0.165 & 0.315 \\
\hline G46 & 0.011 & 0.031 & 0.204 & 0.161 & 0.143 & 0.165 & 0.315 \\
\hline G47 & 0.011 & 0.027 & 0.215 & 0.161 & 0.137 & 0.165 & 0.315 \\
\hline H49 & 0.011 & 0.028 & 0.092 & 0.161 & 0.118 & 0.165 & 0.315 \\
\hline H50 & 0.011 & 0.028 & 0.092 & 0.161 & 0.118 & 0.165 & 0.315 \\
\hline H51 & 0.011 & 0.028 & 0.092 & 0.161 & 0.118 & 0.165 & 0.315 \\
\hline H52-H53 & 0.011 & 0.027 & 0.201 & 0.161 & 0.096 & 0.165 & 0.315 \\
\hline H55-H56 & 0.011 & 0.028 & 0.203 & 0.161 & 0.140 & 0.165 & 0.315 \\
\hline J58 & 0.011 & 0.033 & 0.173 & 0.161 & 0.106 & 0.165 & 0.315 \\
\hline J59-J60 & 0.011 & 0.033 & 0.173 & 0.161 & 0.106 & 0.165 & 0.315 \\
\hline J61 & 0.011 & 0.027 & 0.201 & 0.161 & 0.096 & 0.165 & 0.315 \\
\hline J62-J63 & 0.011 & 0.044 & 0.155 & 0.161 & 0.144 & 0.165 & 0.315 \\
\hline K64 & 0.011 & 0.044 & 0.187 & 0.161 & 0.149 & 0.165 & 0.315 \\
\hline K65 & 0.011 & 0.044 & 0.187 & 0.161 & 0.149 & 0.165 & 0.315 \\
\hline K66 & 0.011 & 0.044 & 0.187 & 0.161 & 0.149 & 0.165 & 0.315 \\
\hline L68A & 0.011 & 0.027 & 0.227 & 0.161 & 0.147 & 0.165 & 0.315 \\
\hline L68B & 0.011 & 0.027 & 0.227 & 0.161 & 0.147 & 0.165 & 0.315 \\
\hline M69-M70 & 0.011 & 0.044 & 0.155 & 0.161 & 0.144 & 0.165 & 0.315 \\
\hline M71-M72 & 0.011 & 0.044 & 0.155 & 0.161 & 0.144 & 0.165 & 0.315 \\
\hline M73-M75 & 0.011 & 0.044 & 0.155 & 0.161 & 0.144 & 0.165 & 0.315 \\
\hline N77 & 0.011 & 0.044 & 0.155 & 0.161 & 0.144 & 0.165 & 0.315 \\
\hline N78-N82 & 0.011 & 0.044 & 0.155 & 0.161 & 0.144 & 0.165 & 0.315 \\
\hline P85 & 0.011 & 0.025 & 0.173 & 0.161 & 0.138 & 0.165 & 0.315 \\
\hline P86 & 0.011 & 0.027 & 0.225 & 0.161 & 0.149 & 0.165 & 0.315 \\
\hline Q87-Q88 & 0.011 & 0.027 & 0.225 & 0.161 & 0.149 & 0.165 & 0.315 \\
\hline R90-R93 & 0.011 & 0.051 & 0.223 & 0.161 & 0.136 & 0.165 & 0.315 \\
\hline S94-T98 & 0.011 & 0.051 & 0.223 & 0.161 & 0.136 & 0.165 & 0.315 \\
\hline
\end{tabular}

Source: EU KLEMS (2011) and Statistics Sweden (2015). 
Table 3 Descriptive Statistics

\begin{tabular}{|l|c|c|c|c|c|c|}
\hline & Median & Mean & St. Dev. & Min. & Max. & Obs. \\
\hline Value added & 18,129 & 35,377 & 60,634 & 2,383 & 678,881 & 940 \\
Volume) & 23,614 & 35,248 & 33,433 & 1774 & 186,129 & 940 \\
Hours & 63 & 97 & 99 & 3 & 541 & 940 \\
ICT capital & 5,818 & 9730 & 11,342 & 55 & 56,641 & 940 \\
Non-ICT capital & 17,988 & 55,989 & 146,079 & 572 & $1,441,072$ & 940 \\
R\&D capital & 1,080 & 6,033 & 17,747 & 1 & 140,645 & 940 \\
Software capital & 813 & 1,925 & 2,823 & 14 & 17,217 & 940 \\
Hardware capital & 4,818 & 9,006 & 11,990 & 8 & 76,564 & 940 \\
$\Delta \ln$ Value added & 0.03 & 0.03 & 0.12 & -1.50 & 0.74 & 893 \\
volume) & 0.008 & 0.009 & 0.06 & -0.83 & 0.42 & 893 \\
$\Delta \ln$ Hours & 0.08 & 0.09 & 0.10 & -0.12 & 1.04 & 893 \\
$\Delta \ln$ ICT capital & 0.03 & 0.03 & 0.06 & -0.13 & 1.18 & 893 \\
$\Delta \ln$ Non-ICT capital & 0.03 & 0.03 & 0.06 & -0.18 & 0.78 & 893 \\
$\Delta \ln$ R\&D capital & 0.04 & 0.05 & 0.11 & -0.25 & 2.47 & 893 \\
$\Delta \ln$ Software capital & 0.04 & 0.12 & 0.15 & -0.18 & 1.22 & 893 \\
$\Delta \ln$ Hardware capital & 0.09 & & & & \\
\hline
\end{tabular}

Note: Value added and capital stocks are in millions SEK in 1993 prices. Hours are also in millions.

Source: Statistics Sweden (2015). 
Table 4 Production function regressions for the Swedish non-farm business sector

\begin{tabular}{|c|c|c|c|c|c|c|}
\hline \multirow[b]{3}{*}{ Hours worked $(\ln L)$} & \multicolumn{6}{|c|}{ Dependent variable: Value added } \\
\hline & \multicolumn{2}{|c|}{$\begin{array}{c}\text { Basic regression } \\
\text { OLS }\end{array}$} & \multicolumn{2}{|c|}{$\begin{array}{c}\text { Time adjustment } \\
\text { OLS }\end{array}$} & \multicolumn{2}{|c|}{$\begin{array}{c}\text { Time adjustment } \\
\text { WLS }\end{array}$} \\
\hline & $\begin{array}{l}0.39 * * * \\
(0.115)\end{array}$ & $\begin{array}{l}0.32 * * * \\
(0.117)\end{array}$ & $\begin{array}{l}0.39 * * * \\
(0.115)\end{array}$ & $\begin{array}{l}0.32 * * * \\
(0.118)\end{array}$ & $\begin{array}{l}0.40 * * * \\
(0.107)\end{array}$ & $\begin{array}{l}0.34 * * * \\
(0.112)\end{array}$ \\
\hline ICT capital $\left(\ln K_{I C T}\right)$ & $\begin{array}{l}0.19 * * * \\
(0.056)\end{array}$ & & $\begin{array}{l}0.18 * * * \\
(0.059)\end{array}$ & & $\begin{array}{c}0.17^{* * *} \\
(0.061)\end{array}$ & \\
\hline Software capital $\left(\ln K_{S}\right)$ & & $\begin{array}{c}0.22 * * \\
(0.083)\end{array}$ & & $\begin{array}{l}0.23 * * * \\
(0.084)\end{array}$ & & $\begin{array}{l}0.23 * * \\
(0.088)\end{array}$ \\
\hline Hardware capital $\left(\ln K_{H}\right)$ & & $\begin{array}{c}0.02 \\
(0.048)\end{array}$ & & $\begin{array}{c}0.004 \\
(0.049)\end{array}$ & & $\begin{array}{l}-0.007 \\
(0.049)\end{array}$ \\
\hline Non-ICT capital $\left(\ln K_{N}\right)$ & $\begin{array}{l}0.30 * * * \\
(0.056)\end{array}$ & $\begin{array}{l}0.32 * * * \\
(0.039)\end{array}$ & $\begin{array}{l}0.29 * * * \\
(0.056)\end{array}$ & $\begin{array}{l}0.32 * * * \\
(0.039)\end{array}$ & $\begin{array}{l}0.29 * * * \\
(0.061)\end{array}$ & $\begin{array}{l}0.32 * * * \\
(0.040)\end{array}$ \\
\hline R\&D capital $(\ln R)$ & $\begin{array}{c}0.11^{*} \\
(0.055)\end{array}$ & $\begin{array}{c}0.10^{*} \\
(0.055)\end{array}$ & $\begin{array}{c}0.11^{*} \\
(0.055)\end{array}$ & $\begin{array}{c}0.10^{*} \\
(0.056)\end{array}$ & $\begin{array}{c}0.11^{*} \\
(0.059)\end{array}$ & $\begin{array}{c}0.10^{*} \\
(0.059)\end{array}$ \\
\hline Time dummies & No & No & Yes & Yes & Yes & Yes \\
\hline Adjusted $R^{2}$ & 0.72 & 0.74 & 0.72 & 0.74 & 0.71 & 0.74 \\
\hline No. of obs. & 940 & 940 & 940 & 940 & 940 & 940 \\
\hline
\end{tabular}

Note: The estimates are based on OLS and WLS regressions for 47 industries in the period 1993-2012. Cluster robust standard errors are presented in parenthesis. $* * *, * *, *$ indicate statistical significance at the $1 \%, 5 \%$ and $10 \%$ levels, respectively.

Hardware capital includes computer and telecommunications equipment. WLS estimates are based on weights of the logarithm of value added in current prices.

Table 5 Descriptive Statistics of the logarithmic change of different variables

\begin{tabular}{|c|c|c|c|c|c|c|}
\hline & & Mean & St. Dev. & Min. & Max. & Obs. \\
\hline \multirow{3}{*}{$\begin{array}{l}\Delta \ln \text { Value added } \\
\text { (volume) }\end{array}$} & (overall) & 0.03 & 0.12 & -1.50 & 0.74 & 893 \\
\hline & (between) & & 0.03 & -0.02 & 0.17 & 47 \\
\hline & (within) & & 0.12 & -1.57 & 0.77 & 19 \\
\hline \multirow[t]{3}{*}{$\Delta \ln$ Hours } & (overall) & 0.009 & 0.06 & -0.83 & 0.42 & 893 \\
\hline & (between) & & 0.03 & -0.04 & 0.12 & 47 \\
\hline & (within) & & 0.06 & -0.79 & 0.31 & 19 \\
\hline \multirow[t]{3}{*}{$\Delta \ln$ ICT capital } & (overall) & 0.09 & 0.10 & -0.12 & 1.04 & 893 \\
\hline & (between) & & 0.04 & -0.007 & 0.20 & 47 \\
\hline & (within) & & 0.09 & -0.18 & 0.94 & 19 \\
\hline \multirow[t]{3}{*}{$\Delta \ln$ Non-ICT capital } & (overall) & 0.03 & 0.06 & -0.13 & 1.18 & 893 \\
\hline & (between) & & 0.03 & -0.07 & 0.15 & 47 \\
\hline & (within) & & 0.05 & -0.17 & 1.07 & 19 \\
\hline \multirow[t]{3}{*}{$\Delta \ln R \& D$ capital } & (overall) & 0.03 & 0.06 & -0.18 & 0.78 & 893 \\
\hline & (between) & & 0.04 & -0.18 & 0.10 & 47 \\
\hline & (within) & & 0.05 & -0.20 & 0.71 & 19 \\
\hline \multirow[t]{3}{*}{$\Delta \ln$ Software capital } & (overall) & 0.05 & 0.11 & -0.26 & 2.47 & 893 \\
\hline & (between) & & 0.04 & -0.04 & 0.25 & 47 \\
\hline & (within) & & 0.10 & -0.22 & 2.28 & 19 \\
\hline \multirow[t]{3}{*}{$\Delta \ln$ Hardware capital } & (overall) & 0.12 & 0.15 & -0.18 & 1.22 & 893 \\
\hline & (between) & & 0.08 & -0.18 & 0.27 & 47 \\
\hline & (within) & & 0.13 & -0.30 & 1.06 & 19 \\
\hline
\end{tabular}

Note: Value added and capital stocks are in millions SEK in 1993 prices. Hours are also in millions.

Source: Statistics Sweden (2015). 
Table 6 Production function regressions for the Swedish non-farm business sector

\begin{tabular}{|c|c|c|c|c|c|c|}
\hline \multirow[b]{3}{*}{$\begin{array}{l}\text { Hours worked } \\
(\ln L)\end{array}$} & \multicolumn{6}{|c|}{ Dependent variable: Value added } \\
\hline & \multicolumn{2}{|c|}{$\begin{array}{c}\text { Basic regression } \\
\text { Excl. time dummies }\end{array}$} & \multicolumn{2}{|c|}{$\begin{array}{c}\text { Fixed effects } \\
\text { Incl. time dummies }\end{array}$} & \multicolumn{2}{|c|}{ First differences } \\
\hline & $\begin{array}{c}0.33^{*} \\
(0.168)\end{array}$ & $\begin{array}{l}0.33 * * \\
(0.165)\end{array}$ & $\begin{array}{l}0.40 * * \\
(0.164)\end{array}$ & $\begin{array}{l}0.39 * * \\
(0.165)\end{array}$ & $\begin{array}{l}0.62 * * * \\
(0.098)\end{array}$ & $\begin{array}{c}0.63 * * * \\
(0.098)\end{array}$ \\
\hline $\begin{array}{l}\text { ICT capital } \\
\left(\ln K_{I C T}\right)\end{array}$ & $\begin{array}{l}0.13^{* *} \\
(0.049)\end{array}$ & & $\begin{array}{c}-0.02 \\
(0.087)\end{array}$ & & $\begin{array}{c}0.01 \\
(0.060)\end{array}$ & \\
\hline $\begin{array}{l}\text { Software capital } \\
\left(\ln K_{S}\right)\end{array}$ & & $\begin{array}{c}0.13^{*} \\
(0.071)\end{array}$ & & $\begin{array}{l}-0.004 \\
(0.076)\end{array}$ & & $\begin{array}{r}-0.03 \\
(0.019)\end{array}$ \\
\hline $\begin{array}{l}\text { Hardware } \\
\text { capital }\left(\ln K_{H}\right)\end{array}$ & & $\begin{array}{c}0.06^{*} \\
(0.030)\end{array}$ & & $\begin{array}{l}-0.004 \\
(0.045) \\
\end{array}$ & & $\begin{array}{l}-0.003 \\
(0.035) \\
\end{array}$ \\
\hline $\begin{array}{l}\text { Non-ICT capital } \\
\left(\ln K_{N}\right)\end{array}$ & $\begin{array}{r}0.27^{* *} \\
(0.113)\end{array}$ & $\begin{array}{c}0.22^{*} \\
(0.118)\end{array}$ & $\begin{array}{c}0.12 \\
(0.120)\end{array}$ & $\begin{array}{c}0.12 \\
(0.120)\end{array}$ & $\begin{array}{c}0.01 \\
(0.082)\end{array}$ & $\begin{array}{c}0.01 \\
(0.084)\end{array}$ \\
\hline $\begin{array}{l}\mathrm{R} \& \mathrm{D} \text { capital } \\
(\ln R)\end{array}$ & $\begin{array}{l}0.33^{* *} \\
(0.145)\end{array}$ & $\begin{array}{l}0.34 * * \\
(0.141)\end{array}$ & $\begin{array}{l}0.29 * * \\
(0.129)\end{array}$ & $\begin{array}{l}0.29 * * \\
(0.129)\end{array}$ & $\begin{array}{l}0.21 * * * \\
(0.040)\end{array}$ & $\begin{array}{r}0.20 * * * \\
(0.040)\end{array}$ \\
\hline Time dummies & No & No & Yes & Yes & Yes & Yes \\
\hline Adjusted $R^{2}$ & 0.50 & 0.51 & 0.53 & 0.53 & 0.23 & 0.23 \\
\hline No. of obs. & 940 & 940 & 940 & 940 & 893 & 893 \\
\hline
\end{tabular}

Note: The estimates are based on fixed effects regressions for the period 1993-2012. Robust standard errors are presented in parenthesis. $* * *, * *, *$ indicate statistical significance at the $1 \%, 5 \%$ and $10 \%$ level, respectively. Hardware capital includes computer and telecommunications equipment. 
Table 7 Production function regressions for the Swedish non-farm business sector

\begin{tabular}{|c|c|c|c|c|}
\hline & \multicolumn{4}{|c|}{ Dependent variable: Value added } \\
\hline & $\begin{array}{c}\text { Basic regression } \\
\text { OLS }\end{array}$ & $\begin{array}{c}\text { Basic regression } \\
\text { WLS }\end{array}$ & $\begin{array}{c}\text { Fixed effects } \\
\text { Excl. time dummies }\end{array}$ & $\begin{array}{c}\text { Fixed effects } \\
\text { Incl. time dummies }\end{array}$ \\
\hline $\begin{array}{l}\text { Hours worked by low- } \\
\text { skilled labor }\left(\ln L_{L O W}\right)\end{array}$ & $\begin{array}{c}0.35 \\
(1.155)\end{array}$ & $\begin{array}{c}0.45 \\
(1.148)\end{array}$ & $\begin{array}{l}3.18^{* * *} \\
(0.730)\end{array}$ & $\begin{array}{l}2.85 * * * \\
(0.726)\end{array}$ \\
\hline $\begin{array}{l}\text { Hours worked by high- } \\
\text { skilled labor }\left(\ln L_{\mathrm{HIGH}}\right)\end{array}$ & $\begin{array}{c}0.19 \\
(0.929)\end{array}$ & $\begin{array}{c}0.11 \\
(0.932)\end{array}$ & $\begin{array}{c}-1.54 * * * \\
(0.498)\end{array}$ & $\begin{array}{c}-1.41^{* *} \\
(0.544)\end{array}$ \\
\hline ICT capital $\left(\ln K_{I C T}\right)$ & $\begin{array}{c}0.28 \\
(0.264)\end{array}$ & $\begin{array}{c}0.29 \\
(0.271)\end{array}$ & $\begin{array}{c}0.70^{*} \\
(0.366)\end{array}$ & $\begin{array}{c}0.47 \\
(0.377)\end{array}$ \\
\hline Non-ICT capital $\left(\ln K_{N}\right)$ & $\begin{array}{l}0.32 * * * \\
(0.067)\end{array}$ & $\begin{array}{l}0.31 * * * \\
(0.068)\end{array}$ & $\begin{array}{c}-0.49 * * \\
(0.230)\end{array}$ & $\begin{array}{l}-0.50 * * \\
(0.201)\end{array}$ \\
\hline R\&D capital $(\ln R)$ & $\begin{array}{c}0.12 \\
(0.079) \\
\end{array}$ & $\begin{array}{c}0.12 \\
(0.084) \\
\end{array}$ & $\begin{array}{c}-0.11 \\
(0.124)\end{array}$ & $\begin{array}{l}-0.10 \\
(0.132)\end{array}$ \\
\hline $\begin{array}{l}\text { Interaction term: Low- } \\
\text { skilled and ICT } \\
\left(\ln L_{\mathrm{LOW}} \cdot \ln K_{\mathrm{ICT}}\right) \\
\end{array}$ & $\begin{array}{c}-0.03 \\
(0.118)\end{array}$ & $\begin{array}{c}-0.04 \\
(0.119)\end{array}$ & $\begin{array}{c}-0.27^{* * *} \\
(0.081)\end{array}$ & $\begin{array}{c}-0.23 * * * \\
(0.080)\end{array}$ \\
\hline $\begin{array}{l}\text { Interaction term: High- } \\
\text { skilled and ICT } \\
\left(\ln L_{\mathrm{HIGH}} \cdot \ln K_{\mathrm{ICT}}\right) \\
\end{array}$ & $\begin{array}{c}0.005 \\
(0.103)\end{array}$ & $\begin{array}{c}0.01 \\
(0.103)\end{array}$ & $\begin{array}{l}0.21 * * * \\
(0.054)\end{array}$ & $\begin{array}{l}0.17^{* * *} \\
(0.057)\end{array}$ \\
\hline Time dummies & Yes & Yes & No & Yes \\
\hline Adjusted $R^{2}$ & 0.59 & 0.59 & 0.13 & 0.18 \\
\hline No. of obs. & 235 & 235 & 235 & 235 \\
\hline
\end{tabular}

Note: The estimates are based on fixed effects regressions for the period 1993-2012. Robust standard errors are presented in parenthesis. $* * *, * *, *$ indicate statistical significance at the $1 \%, 5 \%$ and $10 \%$ level, respectively.

Table 8 Sensitivity analysis

\begin{tabular}{l|cccc}
\hline \multicolumn{4}{c}{ Dependent variable: Value added } \\
\hline & \multicolumn{2}{c}{ ICT-coefficient } & \multicolumn{2}{c}{ R\&D coefficient } \\
& OLS & WLS & OLS & WLS \\
\hline Baseline regression & $0.18^{* * *}$ & $0.17^{* * *}$ & $0.11^{*}$ & $0.11^{*}$ \\
Drop ICT industries & $0.19^{* * *}$ & $0.18^{* * *}$ & $0.05^{*}$ & 0.05 \\
$1993-2000$ & $0.16^{* * *}$ & $0.16^{* * *}$ & $0.07^{*}$ & $0.07^{*}$ \\
$2001-2007$ & $0.18^{* * *}$ & $0.17^{* * *}$ & $0.12^{* *}$ & $0.13^{* *}$ \\
$2008-2012$ & $0.21^{* *}$ & $0.20^{* *}$ & $0.14^{*}$ & $0.14^{*}$ \\
Manufacturing & $0.48^{* * *}$ & $0.50^{* * *}$ & $0.27^{* * *}$ & $0.28^{* * *}$ \\
Services & $0.18^{* *}$ & $0.19^{* *}$ & 0.05 & 0.04 \\
\hline
\end{tabular}

Note: The estimates are based on OLS and WLS regressions for 47 industries in the period 1993-2012. Robust standard errors are presented in parenthesis. $* * *, * * *$ indicate statistical significance at the $1 \%, 5 \%$ and $10 \%$ level, respectively. Manufacturing is defined as C10-C33 and services as G45-T98 based on ISIC rev 4. The following industries are defined as ICT producing: Computer, electronic and optical products (ISIC C26), telecommunications (ISIC J61) and Computer programming and related activities and information services (ISIC J62-J63). All estimations include time dummy variables. 